\title{
Monitoring the content of ethyl carbamate and copper in organic and conventional
}

\section{cachaça}

\author{
João Henrique do Nascimento e Silva ${ }^{1}$, Marta Regina Verruma-Bernardi ${ }^{\circledR}$, Simone Daniela Sartorio de Medeiros ${ }^{1} \odot$, Alessandra \\ Lopes de Oliveira ${ }^{2 *}$
}

IUniversidade Federal de São Carlos/CCA - Depto. de Recursos Naturais e Proteção Ambiental, Rod. Anhanguera, km 174 - 13600-970 - Araras, SP - Brasil.

2Universidade de São Paulo/FZEA - Depto. de Engenharia de Alimentos, Av. Duque de Caxias Norte, 225 - 13635-900 Pirassununga, SP - Brasil.

*Corresponding author <alelopes@usp.br>

Edited by: Luís Guilherme de Lima Ferreira Guido

Received January 28, 2019

Accepted April 09, 2019
ABSTRACT: Ethyl carbamate $(\mathrm{EC})\left(\mathrm{NH}_{2} \mathrm{COOCH}_{2} \mathrm{CH}_{3}\right)$ is found in cachaça, and its presence in the beverage is conspicuous for its toxicity. Copper, the metal of choice used in the construction of stills, is also considered a beverage contaminant and is often related to the presence of $\mathrm{EC}$ in beverages. The study aimed to monitor the quality of cachaça by measuring the presence of copper and EC, and comparing the influences of sugarcane cultivation systems on the concentration of these contaminants. The varieties, RB 867515, RB 962869 and RB 85553, were cultivated under the following management systems: planting without fertilization; organic planting; and conventional planting. For cultivation, a completely randomized design in a factorial scheme of 3 varieties $\times 3$ managements was used as experimental planning, in 4 replications. The concentrations of copper and EC in beverages were evaluated and submitted to univariate analysis of variance $(p \leq 0.05)$. The organic and conventional systems presented no significant variations in copper content, both of which are recommended for the planting of sugarcane as raw material for cachaça. From amongst the varieties evaluated, RB966928 presented the lowest concentrations of copper for the organic and conventional systems, and was the most recommended for the production of cachaça. To evaluate the EC concentration $\left(\mu \mathrm{L}^{-1}\right)$ in the cachaças produced, all beverages were considered in accordance with national legislation. Significant differences were observed between them, but the conventional and organic systems are favored for deployment in the cultivation of sugarcane as the raw material of cachaça. The same applies to the RB966928, RB867515 and RB855453 varieties.

Keywords: contaminants, sugarcane, managements, varieties, toxicity

\section{Introduction}

Ethyl carbamate is a compound known as urethane, belonging to the group of organic compounds classified as ethyl esters of carbamic acid $\left(\mathrm{CH}_{3} \mathrm{NO}_{2}\right)$. The commercial application of EC is well-established, as a solubilizer and co-solvent for pesticides, cosmetics and drug syntheses (Ghanayem, 2007). When administered in large quantities, it can be a precursor to serious health hazards, mainly due to carcinogenic activity to the extent that the International Agency for Research on Cancer (IARC), based on several studies reporting the toxicity of $\mathrm{EC}$, has given it a class $2 \mathrm{~B}$ assignation, which is a category of carcinogenic substances for humans (Alexander et al., 2007). In Brazil, the official method for the determination of EC in distilled beverages was developed by the Ministry of Agriculture, Livestock and Supply (MAPA, 2014).

Copper is another inorganic contaminant present in cachaça and many studies correlate the formation of EC with the presence of copper, as can be seen in this review of this subject, with urea being one of the routes proposed for its formation. In distillation or even after this process, cyanide $\left(\mathrm{CN}^{-}\right)$is also classified as a precursor to EC. Another pathway involving the cyanide $(\mathrm{CN}-)$ ion for the formation of ECCE, occurs as a result of the enzymatic action and oxidation of cyanogenic glycosides (Alexander et al., 2007; Galinaro et al., 2015).
Copper is an essential heavy metal in trace levels, and the Food Nutritional Board (FBN) recommends an RDA (Recommended Dietary Alowance) of 1.5 to $3.0 \mathrm{mg}$ per day for adults (Institute of Medicine, 2001). Prashanth et al. (2015) reported copper levels at 2.0 to $5.0 \mathrm{mg}$ per day for adults. When consumed in high concentrations it will produce toxic effects such as vomiting, gastrointestinal irritation, diarrhea, seizures and epilepsy and serious liver dysfunctions such as Wilson's disease, hepato-lenticular degeneration leading to the destruction of liver and nerve tissue (Kaplan and Maryon, 2016). For cachaça to be marketed and consumed it requires that the compounds are at levels of concentration allowed by the legislations. Copper is the only metal whose concentration is regulated by Brazilian legislation is limited to $5 \mathrm{mg} \mathrm{L}^{-1}$ (Brazil, 2005).

Studies on varieties and management systems of sugarcane on the incidence of EC and copper levels in cachaça are not found in the scientific literature. Therefore, the aim of this present study was to analyze and quantify the contaminants carbamate of ethyl and copper, in the remains of stills, produced from the reeds grown under organic and conventional management for three different varieties. It is a very complex study that tries to correlate the methods of cultivation of the sugar cane and the contaminants of the drink at certain stages of the process. 


\section{Materials and Methods}

\section{Sugarcane cultivation}

The experiment was set up at Araras city, in the state of São Paulo, Brazil, located at the coordinates $22^{\circ} 30^{\prime} 73.61^{\prime \prime} \mathrm{S}$ latitude and $47^{\circ} 37^{\prime} 53.39^{\prime \prime} \mathrm{W}$ longitude, with a local altitude of $629 \mathrm{~m}$, slightly sloping relief and humid temperate climate with a dry winter and hot summer, and predominance of drought in the winter and rain in the summer. The average temperature for the period of the experiment was $20.3{ }^{\circ} \mathrm{C}$ and average rainfall $60.6 \mathrm{~mm}$.

The procedures adopted for the preparation of the area were the fallow of the area for a period of one year, with the intention of respecting the current regulations of MAPA for organic agriculture, as set out in Normative Instruction $\mathrm{N}^{\circ} 46$ of Feb $06^{\text {th }}, 2011$ (MAPA, 2011).

For the planting to begin, a furrow opening was made with a standard spacing of $1.5 \mathrm{~m}$, as adopted by UFSCAR (University of San Carlos, Brazil) and subsequent squaring of plots. The inputs were added to each treatment, using the recommendation of fertilization and liming as a basis. Organic fertilization was applied as stipulated by Kiehl (1985) as well as mineral fertilization as recommended by Raij et al. (2001).

Management adopted the RB 867515, RB 966928 and RB 855453 varieties (without fertilization, neither organic nor conventional) and the inputs were applied to the plots, as follows: treatment without fertilization, organic treatment in which organic compound fertilizer was used, and conventional treatment which used mineral fertilization or limestone without the addition of corrective.

In the organic treatment, the organic compound fertilizer the amount used was $81.67 \mathrm{~kg} \mathrm{plot}^{-1}$. Limestone was applied in the amount of $11.25 \mathrm{~kg} \mathrm{plot}^{-1}$. Spontaneous weeds were controlled by manual weeding.

Under the conventional treatment, mineral fertilization was employed in the amounts of $22.5 \mathrm{~kg}$ using the formula $6: 30: 20(\mathrm{~N}: \mathrm{P}: \mathrm{K})$ and $2.5 \mathrm{~kg}$ of potassium chloride, making $25 \mathrm{~kg}$ in total. They were applied at the rate of $2.08 \mathrm{~kg} \mathrm{plot}^{-1}$. Limestone was applied in the amount of $11.25 \mathrm{~kg} \mathrm{plot}^{-1}$ and spontaneous weeds were controlled by the application of the herbicide glyphosate in a dosage of $2.5 \mathrm{~kg} \mathrm{ha}^{-1}$.

\section{Production of cachaça}

The harvesting and destrawing of the sugarcane were conducted manually and the grinding was carried out in a mill with a grinding capacity of $65 \mathrm{~kg} \mathrm{ha}^{-1}$ on the same day of cutting.

The process, from grinding and beverage production, consisted of nine batches, with four treatments processed each time, since the pilot plant has four fermentation tanks. At the end of each grinding, the con- tent of the soluble solids in the juice extracted from the sugarcane was measured, using a saccharimeter and, where there was a need to calibrate to $16^{\circ}$ Brix, this was carried out with potable water. After measuring the content of soluble solids, $8 \mathrm{~g}$ of pressed yeast were added for each liter of wort and the fermentation process initiated (Baffa-Junior et al., 2011). In all fermentations, new yeasts were used in each batch to minimize oscillations in the process, conducted in 1,000-L fermentation tanks in stainless steel without a refrigeration system.

Measurements of the fermentation temperature in the tanks were taken with an analog thermometer using a scale of -10 to $110^{\circ} \mathrm{C}$ in divisions of $0.5^{\circ} \mathrm{C}$. The concentration of the soluble solids content was measured using a Brix saccharimeter, on a scale from 0 to $30{ }^{\circ}$ Brix, both procedures with a periodicity of three hours to accompany the fermentation stages.

After fermentation, the wine (a liquid resulting from the fermentation) was subjected to distillation, in a still of three bodies. The vapor for the distillation process was generated by an external furnace multitubular boiler using, as a heat source, the sugarcane bagasse resulting from grinding. The flegma, a liquid resulting from distillation in the still after the cutting process, is the cachaça itself. This liquid flowed into the box of cachaça. During distillation, the fractions "head", "heart" and "tail" were separated. These fractions were separated according to the alcoholic strength they have: the head with 50 to $70 \% \mathrm{v} / \mathrm{v}$ of alcohol, the heart with 38 to $50 \% \mathrm{v} / \mathrm{v}$ of alcohol and the tail with 14 to $38 \%$ $\mathrm{v} / \mathrm{v}$ of alcohol (Serafim et al., 2011). All cachaças were produced in the same plant, using the same fermenter and distiller, to cancel out any interference of the process (equipment) on the copper and ethyl carbamate contents.

\section{Determination of copper}

Copper content was determined by atomic absorption spectrophotometry in a flame atomic absorption device. The conditions for analyses consisted of the flame of air/oxidizing acetylene with air flow 7.5


length $324.7 \mathrm{~nm}$, in a current of $3.5 \mathrm{~mA}$. To make the calibration curve in the determination of copper $\left(\mathrm{Cu}^{2+}\right)$ the reagent $\mathrm{CuCl}_{2}$ analytical grade, was used as well as the ultra-pure demineralized water in a Milli-Q filter, with $18.2 \mathrm{M} \Omega$.

For the preparation of samples, an aliquot of 50 $\mathrm{mL}$ of the distilled beverage was drawn in $250 \mathrm{~mL}$ beckers and evaporated in a water bath until the volume fell to $10 \mathrm{~mL}$. The concentrate was cooled and transferred to a $50 \mathrm{~mL}$ volumetric flask and the volume measured with distilled water.

Firstly, the blank (distilled water) was aspirated to adjust the zero reading on the scale of absorbances and the points of the curve for the samples for the spectrometer burner, successively. The samples were 
continuous ly aspirated so as to determine the readings thereby enabling the standard curve of copper concentration to be drawn. The concentration of $\mathrm{Cu}^{2+}$ was given by the intersection of the line derived from the additions with the axis of abscissas. The result was expressed in milligrams of copper per liter $\left(\mathrm{mg} \mathrm{L}^{-1}\right)$ (MAPA, 2005).

\section{Determination of ethyl carbamate}

The determination of ethyl carbamate in this work was conducted in a gas chromatograph coupled to a mass spectrometer with libraries NIST 11 and NIST 11s; equipped with an automatic split/splitless injector. The temperature of the injector was $250^{\circ} \mathrm{C}$ and the capillary chromatographic column employed had a Supelcowax polar phase $-10(30 \mathrm{~m} \times 0.25 \mathrm{~mm}$ di $\times 0.25 \mu \mathrm{m})$.

The oven temperature was programmed to start at $60{ }^{\circ} \mathrm{C}$ (isotherm of $2 \mathrm{~min}$ ), elevated to a rate of $10{ }^{\circ} \mathrm{C}$ per min until reaching $100{ }^{\circ} \mathrm{C}$ (isotherm of $1 \mathrm{~min}$ ) and again to a rate of $5^{\circ} \mathrm{C}$ per min until recahing $120{ }^{\circ} \mathrm{C}$, and then raised to a range of $20^{\circ} \mathrm{C}$ per min until reaching $230{ }^{\circ} \mathrm{C}$, and maintained at this level for $2 \mathrm{~min}$. The temperature of the interface between $\mathrm{GC} / \mathrm{MS}$ was $250{ }^{\circ} \mathrm{C}$. Helium was used as the drag gas at a flow of $1.0 \mathrm{~mL} \mathrm{~min}^{-1}$, and the injection was performed in splitless mode, with 1 $\mu \mathrm{L}$ of sample (cachaça) directly injected. The mass spectrometer was operated with a source of electron impact ions at $70 \mathrm{eV}$.

The analyses in the mass spectrometer occurred in Scan mode with a scan from 50 to $500 \mathrm{~m} / \mathrm{z}$ as well as ion monitoring in the SIM (Select Ion Monitoring) mode; in this case, the ion monitored was 89 SIM (MAPA, 2014). The SIM mode was applied to increase the detection sensitivity of EC in the cachaças produced.

The quantification of EC was conducted by external standardization; for this, a standard solution with known concentrations of ethyl carbamate was prepared from the dilution of a standard mixture of more concentrated EC. The curve was composed of five points and presented a regression coefficient $\left(\mathrm{R}^{2}\right)$ of 0.9899 .

\section{Statistical analysis}

When determining the contaminants /copper and $\mathrm{EC})$, the cachaças derived from sugarcane planting without fertilization, with organic and conventional fertilization, followed a completely randomized design (CRD) in factorial scheme 3 (varieties) $\times$ 3 (managements), which was carried out in 4 repetitions.

Each plot was $37 \mathrm{~m}^{2}$, with five furrows $5 \mathrm{~m}$ in length and spacing $1.5 \mathrm{~m}$ between lines, where the three central furrows formed a useable area in the plot with two lateral furrows as borders.

The results of the concentration of these compounds present in the cachaça were evaluated and subjected to univariate analysis of variance $(p \leq 0.05)$. When necessary, the Tukey multiple mean comparison test was employed, using the $R$ Development Core Team $^{\circledR}$ software program (2011).

\section{Results and Discussion}

\section{Copper}

The concentration of copper $\left(\mathrm{mg} \mathrm{L}^{-1}\right)$ in the cachaças produced by the sugarcane from the different varieties cultivated under different management systems, indicated a significant double interaction $(p=0.01424)$, i.e, for the copper concentration, the sugarcane was dependent on management (Table 1) for at least one of the varieties studied.

When evaluating the varieties (Table 1), it was observed that the amount of copper in the cachaças from the RB966928 variety was smaller and differed from the beverages produced with the RB855453 and RB86751 varieties in the organic management. The same behavior was observed under the conventional management system, but under management without fertilization, the copper concentration was lower in the cachaça prepared from the RB867515 variety and demonstrated no differences from the RB966928 variety, only from the beverage produced from the RB855453 variety.

The RB 867515 variety was the only one to present significant variation between treatments revealing higher concentrations of copper under both organic and conventional management indicating a lower concentration of copper when no fertilization was used in the soil. This information is important to producers of cachaça. According to Dal-Bianco (2012), with the genetic improvement and tools of sugarcane biotechnology plus the launch of the first variety more than forty years ago, the market had only five varieties worthy of note. This scenario has now changed, with twice the number of sugar cane varieties available to the national market and the $\mathrm{RB}$ varieties responsible for $65 \%$ of the cultivated sugarcane area, growing the RB966928 variety, commanding $17 \%$ of the areas with RB 867515 in second place, with $16 \%$ (Carneiro et al., 2016). Consequently, knowledge of the variety and influence on the production of cachaça, related to its contaminants, is required.

Table 1 - Result of the unfolding of the double interaction (varieties $\times$ managements) for copper concentration.

\begin{tabular}{|c|c|c|c|}
\hline \multirow{2}{*}{ Management } & \multicolumn{3}{|c|}{ Variety } \\
\hline & RB867515 & RB855453 & RB966928 \\
\hline & \multicolumn{3}{|c|}{$\mathrm{mg} \mathrm{L}^{-1}$} \\
\hline Organic & $3.87^{\mathrm{Aa}}( \pm 0.90)$ & $3.77^{\mathrm{Aa}}( \pm 0.41)$ & $3.20^{\mathrm{Ba}}( \pm 0.25)$ \\
\hline Conventional & $3.82^{\mathrm{Aab}}( \pm 0.11)$ & $3.80^{\mathrm{Aa}}( \pm 0.39)$ & $3.17^{\mathrm{Ba}}( \pm 0.33)$ \\
\hline Without fertilization & $3.07^{\mathrm{Bb}}( \pm 0.06)$ & $3.55^{\text {Aa }}( \pm 0.42)$ & $3.18^{\mathrm{Ba}}( \pm 0.90)$ \\
\hline
\end{tabular}


With regard to the sugarcane varieties for determining the copper concentration in the cachaças produced with RB966928 and RB855453, no differences were seen between treatments (Table 1). However, there was a difference in copper concentration for the cachaça produced by the RB867515 variety, with the highest concentration detected in the cachaça from the organic management, which did differ from management without fertilization, but not from conventional management (Table 1). The results presented in this research differ from those determined by Gabriel et al. (2012), who found no differences in copper concentration in the cachaças produced with different cane varieties and types of fermentation under organic management, for example.

Even when a copper distiller was used, variations in this metal in the cachaça were not significant (from $3.07 \mathrm{mg} \mathrm{L}^{-1}$ to $3.87 \mathrm{mg} \mathrm{L}^{-1}$ ). Although there were variations in copper concentration between the beverages, none of the results presented a copper content above that allowed by the Brazilian legislation, which has a ceiling of $5.0 \mathrm{mg} \mathrm{L}^{-1}$ of copper.

The low values of this element in cachaça corroborate those presented by Bortoletto and Alcarde (2015) and Gabriel et al. (2012). Nevertheless, they are different from the values obtained by Fernandes et al. (2007) and Pereira et al. (2012), who determined copper concentration in cachaças and detected levels above that allowed by the legislation.

Nevertheless, due to the copper concentration (Table 1) in the cachaças in this research study, it would not be possible to export them to Europe, since the legislation of that continent requires a maximum value of 2.0 $\mathrm{mg} \mathrm{L}^{-1}$ of copper in alcoholic beverages.

\section{Ethyl carbamate (EC)}

Figure 1 presents the chromatogram of total EC ions in a known concentration $\left(\mu \mathrm{g} \mathrm{L}^{-1}\right)$. These analy- ses were conducted in triplicate and the overlap of the peaks indicates the linearity and reproducibility of the data. A standard solution of ethyl carbamate injected in different concentrations presented the same retention times (13.25 $\mathrm{min})$. In the mass spectrum of ethyl carbamate (Figure 2), the similarity presented between the spectrum and that of the NIST library of the equipment was $98 \%$.

The analysis of variance of EC concentration $(\mu \mathrm{g}$ $\mathrm{L}^{-1}$ ) in the cachaças produced indicated a significant double interaction ( $p=0.01254)$ In other words, for EC concentration, the sugarcane variety was dependent on management in at least one case.

The cachaças produced from the three sugarcane varieties produced with the organic and conventional (mineral) managements differed from each other. Nevertheless, under the management without fertilization system, there was significant variation only in the EC concentration of the cachaça produced from the RB 966928 variety in relation to the others. The cachaças derived from the RB 867515 and RB 966928 varieties presented differences in EC concentrations under all management systems. However, the RB 855453 variety presented difference for the same variable under the conventional management system only (Table 2 ).

The highest concentration of EC in the cachaças analyzed was from the beverage produced from the RB 966928 variety, under conventional management, being $114.20 \mu \mathrm{g} \mathrm{L}^{-1}$ of beverage, followed by the cachaça produced from the RB867515 variety, under organic management, being $77.60 \mu \mathrm{g} \mathrm{L}^{-1}$ of beverage. The lowest EC level in the cachaças was observed in the beverage produced from the RB 966928 variety, with 22.47 $\mu \mathrm{g} \mathrm{L}^{-1}$, followed by the cachaça produced from the RB 867515 variety, with $31.05 \mu \mathrm{g} \mathrm{L}^{-1}$, both under management without fertilization. Special attention should be paid to this result, since these varieties are the most

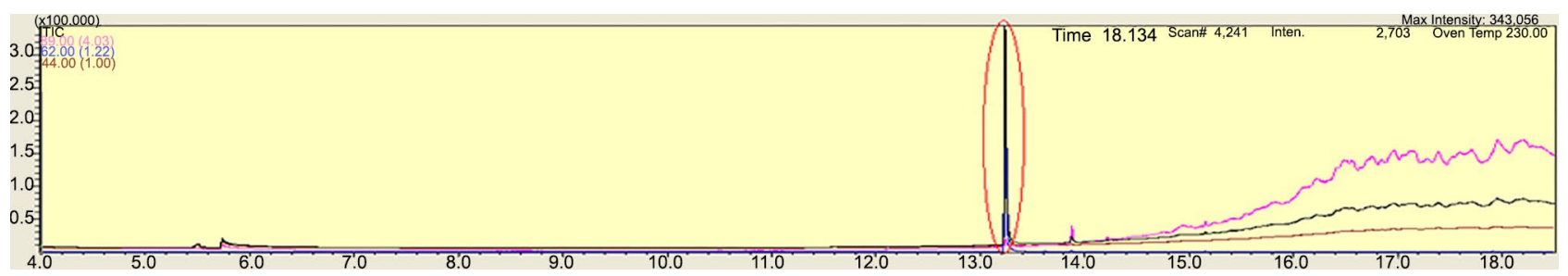

Figure 1 - Total ion chromatogram (TIC) of ethyl carbamate.

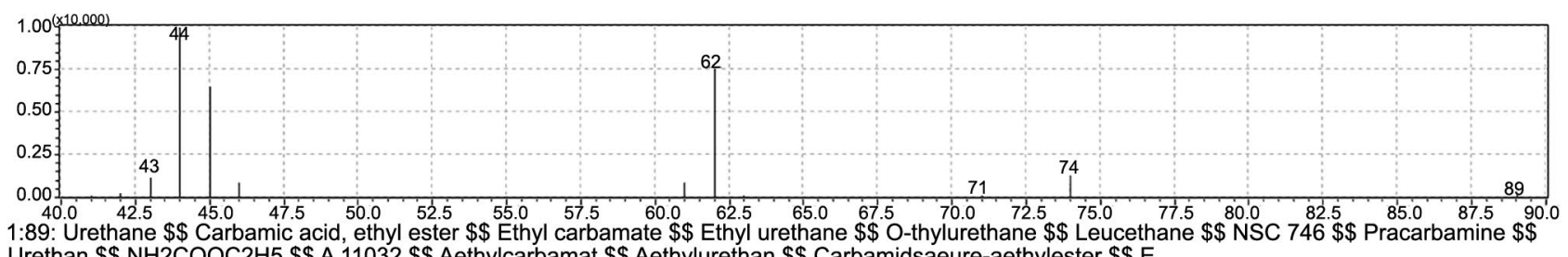

Urethan \$ NH2COOC2H5 \$ A 11032 \$ Aethylcarbamat \$ Aethylurethan \$ Carbamidsaeure-aethylester \$ $\$$

Figure 2 - Mass spectrum of ethyl carbamate. 
Table 2 - Average of Tukey results in unfolding the double interaction (varieties $\times$ managements) for the concentration of ethyl carbamate.

\begin{tabular}{lrrr}
\hline Management & \multicolumn{3}{c}{ Variety } \\
\cline { 2 - 4 } & RB867515 & RB855453 & RB966928 \\
\hline & & $\mu g L^{-1}$ of cachaça & $46.77^{\mathrm{Bb}}( \pm 0.87)$ \\
Organic & $77.60^{\mathrm{Aa}}( \pm 0.26)$ & $31.95^{\mathrm{Cb}}( \pm 0.55)$ & $114.20^{\mathrm{Aa}}( \pm 1.25)$ \\
Conventional & $46.70^{\mathrm{Cb}}( \pm 0.85)$ & $55.27^{\mathrm{Ba}}( \pm 0.77)$ & $22.47^{\mathrm{BC}}( \pm 0.99)$ \\
Without fertilization & $31.05^{\mathrm{AC}}( \pm 1.55)$ & $31.25^{\mathrm{Ab}}( \pm 0.55)$ & \\
\hline
\end{tabular}

Values in the same line, followed by identical capital letters, or in the same column followed by identical lowercase letters indicate that, at the level of ( $p<0.05$ ), there was no difference between the means.

commonly cultivated compared to the others included in this experiment and consequently, are the most often seen in the Brazilian sugarcane-energy market.

The cachaça produced from the RB 966928 variety, under conventional management, presented the highest level of EC, more than twice the other beverages. If we consider the process, this value can be attributed to the cut between the fractions in the process of separation of the distillate (head, heart and tail); the fractions' head and tail of the distillation process have higher EC levels (Baffa-Junior et al., 2011) and a part of them may have been mixed in with the heart fraction.

Analyzing the results (Table 2) of the EC levels in the cachaças produced, it can be concluded that the sugarcane used and the sugarcane variety used for the production of cachaça can influence the levels of this contaminant in the final product.

It is emphasized that all cachaças produced from this study presented EC levels within the Brazilian legislation, the maximum value allowed being $210 \mu \mathrm{g} \mathrm{L} \mathrm{L}^{-1}$ of the beverage. The authors Borges et al. (2014) and Zacaroni et al. (2015) also found, in their experiments, EC contents below the current national legislation ceiling. On the other hand, Masson et al. (2014) and BaffaJunior et al. (2011) observed that the EC levels in a number of cachaça samples they analyzed were above the maximum allowed by the legislation in Brazil.

This study presented significant differences in ethyl carbamate content in cachaças between the varieties and methods of cultivation. A possible explanation is that sugarcane varieties differ in relation to their adaptation to the type of soil, climate etc., which affects nitrogen absorption and metabolism in the plant; therefore, the musts present variations in the amounts and types of nitrogen compounds, precursors in the formation of ethyl carbamate. Corroborating this hypothesis, the sugarcane without fertilization presented inferior ethyl carbamate values compared to those of the organic and conventional cultivation systems (Table 2).

Although our research did not show samples of beverages with higher EC values than that allowed by the legislation, it is important to present certain studies undertaken with the intention of reducing this contaminant in alcoholic beverages.

Studies on the alcoholic beverage manufacturing process and the proposition of modifications in the process steps that aim to minimize the formation of this contaminant can be found from the beginning of the 90's to the present day. Distillation in copper stills has received special attention in studies about the influence of the process on the formation of EC since copper is the precursor of this contaminant.

Aylott et al. (1990) demonstrated different forms of ethyl carbamate formation as a function of their precursors in the course of whiskey storage. They indicated that, in order to minimize the amount of EC in the beverage, the monitoring of these precursors is important.

With regard to the production of cachaça, there are also several studies that propose implications and opinions on modifications of the process to mitigate the amount of EC in the beverage. For example, double distillation with high reflux rates in the distilleries resulted in considerably decreasing EC content in the cachaça (Alcarde et al., 2012a). Similarly, when decreasing the amount of ethyl carbamate in cachaça, it also contributed to changing the configuration of copper stills under different condensation systems (Alcarde et al., 2012b).

In addition to the focus on monitoring EC precursors in the process and storage of beverages, the identification of critical control points (CCPs) for good cachaça handling practices and the implementation of Hazard Analysis Critical Control Points (HACCP) in small plants (Bortoletto et al., 2018) are both imperative. Furthermore, the use of low-contamination cachaça in the production of cachaça has been the subject of recent research.

\section{Conclusion}

Not one of the copper concentration values $\left(\mathrm{mg} \mathrm{L}^{-1}\right)$ exceeded that allowed by Brazilian legislation; organic and conventional cropping systems did not yield significant variations between them. Thus, both are recommended for the planting of sugarcane as sugarcane liquor. From amongst the varieties evaluated, RB966928 presented the lowest concentrations of copper for organic and conventional cropping systems, and is the most suited to the production of cachaça.

With regard to EC concentration $\left(\mu \mathrm{g} \mathrm{L}^{-1}\right)$ in the cachaças produced, it was verified that all beverages were in compliance with national legislation. It was ob- 
served that differences were found between the varieties,. Nevertheless, both the conventional and organic systems can be applied to the cultivation of sugarcane as the raw material of cachaça. The same is true for all three varieties: RB966928, RB867515 and RB855453.

It is noteworthy that monitoring of EC precursors in the beverage process and storage is essential to maintaining contaminant levels in line with the legislation, but the identification of critical control points (CCPs) for good cachaça handling practices and the implementation of Hazard Analysis and Critical Control Points (HACCP) are actions that are neither demanding nor costly, and contribute to the quality of the beverage.

\section{Authors' Contributions}

Conceptualization: Silva, J.H.N.; Oliveira, A.L. Data acquisition: Silva, J.H.N. Data analysis: Silva, J.H.N.; Verruma-Bernardi, M.R.; Oliveira, A.L. Design of Methodology: Verruma-Bernardi, M.R.; Oliveira, A.L.; Medeiros, S.D.S. Writing and editing: Silva, J.H.N.; Verruma-Bernardi, M.R.; Oliveira, A.L.; Medeiros, S.D.S.

\section{References}

Alcarde, A.R.; Souza, L.M.; Bortoletto, A.M. 2012a. Ethyl carbamate kinetics in double distillation of sugar cane spirit. Part 2. Influence of type of pot still. Journal of the Institute of Brewing 118: 352-355.

Alcarde, A.R.; Souza. L.M.; Bortoletto, A.M. 2012b. Ethyl carbamate kinetics in double distillation of sugar cane spirit. Journal of the Institute of Brewing 118: 27-31.

Alexander, J.; Gudjón A.A.; Benford, D.; Cockburn A.; JeanPierre C.; Dogliotti, E.; Di Domenico, A.; Férnandez-Cruz, M.L.; Fürst, P.; Fink-Gremmels, J.; Galli, C.L.; Grandjean, P.; Gzyl, J.; Heinemeyer, G.; Johansson, N.; Mutti, A.; Schlatter, J.; Leeuwen, R.V.; Peteghem, C.V.; Verger, P. 2007. Ethyl carbamate and hydrocyanic acid in food and beverages scientific opinion of the panel on contaminants. European Food Safety Authority Journal 551: 1-44.

Aylott, R.I.; Cochrane, G.C.; Leonard, M.J.; MacDonald, L.S.; MacKenzie, W.M.; McNeish, A.S.; Walker, D.A. 1990. Ethyl carbamate formation in grain based spirits. Part I. Postdistillation ethyl carbamate formation in maturing grain whisky. Journal of the Institute of Brewing 96: 213-221.

Baffa-Júnior, J.C.; Mendonça, R.C.S.; Kluge, J.M.D.A.T.; Pereira, J.A.M.; Soares, N.D.F.F. 2011. Ethyl-carbamate determination by gas chromatography-mass spectrometry at different stages of production of a traditional Brazilian spirit. Food Chemistry 129: 1383-1387.

Bortoletto, A.M.; Silvello, G.C.; Alcarde, A.R. 2018. Good manufacturing practices, hazard analysis and critical control point plan proposal for distilleries of cachaça. Scientia Agricola 75: 432-443.

Bortoletto, A.M.; Alcarde, A.R. 2015. Assessment of chemical quality of Brazilian sugar cane spirits and cachaças. Food Control 54: 1-6.
Borges, G.B.V.; Gomes, F.D.C.O.; Badotti, F.; Silva, A.L.D.; Machado, A.M.R. 2014. Selected saccharomyces cerevisiae yeast strains and accurate separation of distillate fractions reduce the ethyl carbamate levels in alembic cachaças. Food Control 37: 380-384.

Carneiro, M.S.; Chapola, R.G.; Fernandes Junior, A.R.; Cursi, D.E.; Barreto, F.Z.; Balsalobre, T.W.A. and Hoffmann, H.P. 2016. RB975242 and RB975201-Late maturation sugarcane varieties. Crop Breeding and Applied Biotechnology 16: 365-370.

Dal-Bianco, M.; Carneiro, M.S.; Hotta, C.T.; Chapola, R.G.; Hoffmann, H.P.; Garcia, A.A.F.; Souza, G.M. 2012. Sugarcane improvement: how far can we go? Current Opinion in Biotechnology 23: 265-270.

Fernandes, W.J.; Cardoso, M.G.; Vilela, F.J.; Morais, A.R.; Silva, F.V.; Nelson, D.L. 2007. Physicochemical quality of a blend of domestic cachaças from the south of Minas Gerais. Journal of Food Composition and Analysis 20: 257-261.

Gabriel, A.V.M.D.; Verruma-Bernardi, M.R.; Margarido, L.A.C.; Borges, M.T.M.R.; Nassu, R.T.; Lavorenti, N.A.; CeccatoAntonini, S.R. 2012. Effect of the spontaneous fermentation and the ageing on the chemo-sensory quality of Brazilian organic cachaça. Ciência Rural 42: 918-925.

Galinaro, C.A.; Ohe, T.H.; Silva, A.C.; Silva, S.C.; Franco, D.W. 2015. Cyanate as an active precursor of ethyl carbamate formation in sugar cane spirit. Journal of Agricultural and Food Chemistry 33: 7415-7420.

Ghanayem, B.I. 2007. Inhibition of urethane-induced carcinogenicity in Cyp2e1/- in comparison to Cyp 2e1+/+ mice. Toxicological Sciences 95: 331-339.

Institute of Medicine. 2001. Dietary Reference Intakes for Vitamin A, Vitamin K, Arsenic, Boron, Chromium, Copper, Iodine, Iron, Manganese, Molybdenum, Nickel, Silicon, Vanadium, and Zinc. National Academies Press, Washington, DC, USA.

Kaplan, J.H.; Maryon, E.B. 2016. How mammalian cells acquire copper: an essential but potentially toxic metal. Biophysical Journal 110: 7-13.

Kiehl, E.J. 1985. Organic Fertilizers = Fertilizantes Orgânicos. Agronômica Ceres, São Paulo, SP, Brazil (in Portuguese).

Masson, J.; Cardoso, M.G.; Zacaroni, L.M.; Anjos, J.P.; Santiago, W.D.; Machado, A.M.D.R.; Nelson, D.L. 2014. GC-MS analysis of ethyl carbamate in distilled sugar cane spirits from the northern and southern regions of Minas Gerais. Journal of the Institute of Brewing 120: 516-520.

Ministério da Agricultura, Pecuária e Abastecimento [MAPA] 2014. Work Instruction $\mathrm{n}^{\circ}$ IT LABV 377, of December 20, 2014. IT LABV 377, Rev. 01 - Determination of Ethyl Carbamate in Alcoholic Beverages Distilled by GC-MS = Instrução de trabalho ${ }^{\circ}$ IT LABV 377, de 20 de dezembro de 2014. IT LABV 377, Rev. 01 - Determinação do Carbamato de Etila em Bebidas Alcoólicas Destiladas por GC-MS. MAPA, Brasília, DF, Brazil (in Portuguese).

Ministério da Agricultura, Pecuária e Abastecimento [MAPA] 2014. Normative Instruction $\mathrm{n}^{\circ}$ 28: Alters sub-item 5.1.2 of the annex of the Normative Instruction $n^{\circ} 13=$ Instrução Normativa $\mathrm{n}^{\circ}$ 28: Altera o subitem 5.1.2 do anexo da Instrução Normativa ${ }^{\circ}$ 13. Diário Oficial da União, Brasília, 11 de agosto de 2014, Seção 1, p.11 (in Portuguese). 
Ministério da Agricultura, Pecuária e Abastecimento [MAPA]. 2011. Normative Instruction $n^{\circ}$ 46: Establish the technical regulation for organic production systems = Instrução Normativa $n^{\circ}$ 46: Estabelecer o regulamento técnico para sistemas de produção orgânica. Diário Oficial da União, Brasília, 7 de outubro de 2011, Seção 1, p.10 (in Portuguese).

Ministério da Agricultura, Pecuária e Abastecimento [MAPA]. 2005. Normative Instruction $n^{\circ} 13$ : Technical regulation for setting Identity and quality standards for spirit sugar cane and cachaça $=$ Instrução Normativa $n^{\circ} 13$ : Regulamento Técnico para estabelecimento de padrões de identidade e qualidade para a cana-de-açúcar e cachaça. Diário Oficial da União, Brasília, 30 de junho de 2005, Seção 1, p.11 (in Portuguese).

Pereira, R.F.; Vidal, C.B.; Lima, A.C.; Melo, D.Q.; Dantas, A.N.; Lopes, G.S.; Silva, M.N. 2012. Chemometric characterization of alembic and industrial sugar cane spirits from Cape Verde and Ceará, Brazil. International Journal of Analytical Chemistry. 2012: article 840528. Doi 10.1155/2012/840528.
Prashanth, L.; Kattapagari, K.K.; Chitturi, R.T.; Baddam, V.R.R.; Prasad, L.K. 2015. A review on role of essential trace elements in health and disease. Journal of Dr. NTR University of Health Sciences 4: 75-78.

Raij, B.Van.; Andrade, J.C.; Cantarella, H.; Quaggio, J.A. 2001. Chemical Analysis of Fertility of Tropical Soils = Análise Química da Fertilidade de Solos Tropicais. Instituto Agronômico, Campinas, SP, Brazil (in Portuguese).

Serafim, F.A.T.; Buchviser, S.F.; Galinaro, C.A.; Franco, D.W.; Novaes, F.V. 2011. Organic acids in sugarcane spirits' fractions produced in stills and columns. New Chemistry 34: 28-32 (in Portuguese, with abstract in English).

Zacaroni, L.M.; Magriotis, Z.M.; Cardoso, M.G.; Santiago, W.D.; Mendonça, J.G.; Vieira, S.S.; Nelson, D.L. 2015. Natural clay and commercial activated charcoal: properties and application for the removal of copper from cachaça. Food Control 47: 536-544. 